\title{
Interactions between Quality of Life at Work and Family: Integrative Review
}

Rosana Maria Barreto Colichi ${ }^{1}$, Silvia Cristina Mangini Bocchi ${ }^{2}$, Silvana Andrea Molina Lima ${ }^{3}$, Regina Célia Popim²

\section{Abstract}

Background: The family is one of the most important components of people's quality of work life (QWL). This study aims to identify the production of knowledge in national and international journals about the interactions between QWL and family relationships.

Method: This is an integrative review of literature, carried out from 2011 to 2016, in the databases: Medline, LILACS, Index Psychology - scientific technical journals, BDENF-nursing, SciELO.ORG, CINAHL, EMBASE, SCOPUS, PubMed and Web of Science. Full-text articles in Portuguese, English and Spanish were available for free in these databases.

Results: The corpus of analysis consisted of 83 articles, where $95 \%$ of the researchers focused their studies on: a) concepts and dimensions; B) conflicts and balance; C) influence of work in the family; D) health;

E) diagnosis; and F) enrichment.

Conclusions: There was a lack of studies on the influence of the family and the family environment on work and the possible correlations of QWL and family functionality, denoting the need for future research on these two aspects, aiming to deepen understanding for the improvement of QWL Organizations.

\section{Introduction}

In all institutions, public or private, industrial, commercial institution or care institution, with or without profits, there will always be goals, resources and staff and internal organization. In these places, which we call "work environment", the employees will establish routines,
1 Administrator, Ms, São Paulo State University (Unesp), Botucatu Medical School, Campus Botucatu, Brazil.

2 RN, PhD, Associate Professor at São Paulo State University (Unesp), Botucatu Medical School, Campus Botucatu, Brazil.

3 RN, PhD, Assistant Professor at São Paulo State University (Unesp), Botucatu Medical School, Campus Botucatu, Brazil.

\section{Contact information:}

\section{Rosana Maria Barreto Colichi.}

Address: Rua Plácido Rodrigues Venegas, 226, Jardim Paraíso, Botucatu, São Paulo, Brasil. CEP: 18610-180.

Tel: +55 14 99662-1937

”rosana@fmb.unesp.br

Keywords

Quality of Work Life; Family; Family Functionality. 
process and social relationship, in a constant interaction with their hierarchical superiors, co-workers, clients, patients and others people groups.

The "job" is frequently the subject of studies of several researchers, as well as a number of factors that might increase or decrease the quality of people's life at work. There are lines of researches about occupational medicine, ergonomics, physical therapy, and management among several others.

The Quality of Work Life (QWL) is still broadly studied in knowledge fields like psychology and sociology, and one of its greatest challenges is to overcome the fragmentation of the lines of research and the dissemination of production in different areas of knowledge such as administration, health, law, and engineering, among many others [1].

The human searches identity and reason in their work life. More than the company profits, the statistic goals, the quality or the population service, people desire further than the balanced financial support, they want to make of their occupation a source of personal satisfaction and fulfillment. Thus, the QWL is directly related to the individual well being, approaching all aspects of the life of this worker. Because of its complexity, the human being must be always assessed in a whole way, widening the views even for the social field [2].

However, the social questions are much more embracing and subjective than it looks like. One of the facets of the human being is the importance of conviviality in the family system and their perception of this functionality. Considering that the person is the result of a group structure, named family, this social unity becomes one of the variables to be studied. The relationship of belonging to a group comes from the family process where it is learned the group structure that will give you support base for coexistence with other groups [3].

Similarly to the QWL, the family also presents large diversity of concepts to the more diverse sciences and disciplines. Nonetheless, since it is important to establish a structure which allows us a more ac- curate study, we have chosen to adopt a model of structure of family assessment, which helps to organize a massive amount of information apparently disparate, also providing focus of intervention.

In the area of health, it can be observed several studies related to the family, representing an evolution when it is established the systemic understanding of families with experience problems lived by them. In this area it can be found the Calgary Family Assessment Model (CFAM), which is based in theoretical fundament involving systems, cybernetic, communication and change. The model is a multidimensional structure that consists in three main categories: structural, development and functional [4].

The structural analysis refers to the internal, external and contextual family structure. Thus, it is possible to assess the family composition, the bond among its members and others significant elements like the extended family or broader systems, as the context where the family is inserted in. Here it is analyzed internal aspects as gender, sexual orientation, growth order, the existent subsystems and the family boundaries. The external features refer to broader systems of the family. In the context ethnicity, race, social class, religion, spirituality and the environment where the family lives are checked [4].

The development analysis makes it possible to comprehend the exclusive phenomenon of the family, such as its growth and functional, structural and interactional level evolutionary trajectory. In this way, it is possible to analyze the stages, tasks and bonds in the family [4].

The Calgary model allows yet the family functional assessment, which features the way the family members interact one with another. The Instrumental Functioning focuses on the daily activities of the family, while the Expressive Functioning focuses on the interaction patterns, subdivided in nine categories: emotional communication; verbal communication; non-verbal communication; circular communication; problem solving; roles; power and influence; beliefs; alliances and unions. These interaction 
processes seem to have bigger effect on the family health status than on its structure and function [4].

We have considered in this study the third dimension, because we understand that the functional analysis is consequence of the others, representing the "status-quo" of the studied family.

Thus, focusing on the family functionality, we have searched a collection instrument capable of translating this functionality under the perception of the individuals of this research.

One of the instruments used to check the family functionality level is the family APGAR. This research instrument, which was developed in 1928 by SmiIkstein, is composed by five questions that allow to measure the family members' satisfaction related do five basic components in the unity and functionality of any family: adaptation, partnership, growth, affection, and resolution [5]. The Family Apgar was validated, translated and adapted to our culture, for this it was used the transcultural adaptation methodology [6].

The Family Apgar is one of the instruments most used in Nursing in studies that include the assessment and intervention in the family [7]. It is useful to point out the way a person realizes the functioning in their family in a determined moment [8]. In addition, it has advantages such as reduced number of items and ease of application.

It is defined by the acronym APGAR due to the utilization of basic parameters: Adaptation; Participation; Growth; Affection; Resolution. It is constituted by five questions relate to the family function components: satisfaction with the attention given to the family when something bothers the worker, satisfaction with the way the family expresses affection and reacts in relation to the feelings of anger, sadness and love of the worker and the satisfaction with the way the worker spends time with the family.

Due to the importance of the QWL as well as the family relations, it is asked: How is knowledge production configured in national and international journals about the interaction between QWL and workers' family functionality?

Trying to answer that question, it was intended with this work: to perform an integrative review in order to identify the knowledge produced in national and international journals about the interaction between the QWL and the family functionality of these workers.

\section{Methods}

It is an integrative review of literature, construction of an extensive literature review, contributing to discussions about methods and results of researches, as well as reflections on the accomplishment of future studies [9].

The integrative review is defined as instrument to the access, identification, analysis and synthesis of literature of a determined theme, allowing broad vision about the issue, applied methods and result of publications [10]. With this method it is possible to synthesize and produce conclusions about the knowledge produced by studies about determined phenomenon, using guiding question in the search to this literature [11].

In order to perform integrative review it is necessary: problem definition, through the object of the presented review in question or primary hypothesis form; selection of samples after inclusion criteria has been defined; characterization of the studies (the characteristics or information to be collected are defined by means of clear criteria, guided by an instrument); result analysis (to identify similarities and conflicts) and presentation and discussion about the findings [10].

For this study the review guiding question was based in the Population, Intervention, Comparison and Outcomes strategy, known by the abbreviation PICO [12] (P: Population-workers; I: intervention of the family functionality in the QWL; C: workers positively and negatively influenced by the family functionality; O: positive and negative influence of 
the family in the QWL). So, the guiding question was: How does the family functionality interferes in the QWL?

The selection of the sample was established in March 2016, by online access to the health database available at the web portals Periódicos da Coordenação de Aperfeiçoamento de Pessoal de Nível Superior: Capes (www.capes.gov.br) and Bireme Biblioteca Virtual em Saúde (BVS).

At Capes portal, we have found the following database: SciELO, CINAHL, EMBASE, SCOPUS, Web of Science and PubMed. 1) SCIELO - Scientific Electronic Library Online - it is a model for cooperative electronic publishing of scientific journals on Internet, it is developed to respond to the need of scientific communication in developing countries and particularly in Latin America and the Caribbean. 2) Cumulative Index for Nursing and Allied Health Literature (CINAHL), database with more than 3,2 million of records since 1937, which provides the full text of more than 700 nursing and health journals indexed in its database. 3) EMBASE, with relevant and accessible biomedical information, it has more than 30 million summary and indexes of publishing, peer reviewed biomedical literature, printed publishing and conferences. 4) Scopus has 55 million records of 21,915 titles of 5,000 editors; it is considered the largest database of journals, books and annals of scientific events, communication of knowledge produced around the world in the fields of science, technology, medicine, social sciences, arts and humanities. 5) The Web of Science platform is a database that serves more than 7,000 academic and research institutions, national governments, development organizations and publications organizations in more than 100 countries around the world. 6) PubMed base includes more than 24 million citations to the biomedical literature of MEDLINE, journals of science and life, and online books. The citations include links to access the full text of PubMed central publications and publisher websites.
On the Bireme portal - Virtual Library in Health (BVS), we found the following database: Medline, LILACS, Index Psychology- scientific technical journals, BDENF-Nursing. 1) Medline (Medical Literature Analysis and Retrieval System Online) is an online database which offers free access to references and summaries of scientific magazines of biomedical area. Approximately 5,400 periodicals from the United States and 80 countries are indexed on this base. 2) Latin-American and Caribbean Literature in Health Science (LILACS), it is considered the most important and comprehensive index of scientific and technical literature in Latin America and the Caribbean. 3) Index Psychology - Scientific technical journals, it is a database that brings together the technical-scientific literature in Psychology published in journals, with access to the full text when available on a recognized portal with more than 42,000 articles. It is $t$ is maintained by the Brazilian Library Network of Psychology Libraries ReBAP and coordinated by the Virtual Library of Psychology of Brazil. 4) BDENF-Nursing - it is a database of thematic bibliography specialized in the field of Nursing for the access and propagation of nursing publications, usually absent from the national and international bibliographies available in the databases of the Health Science area. It includes bibliographic references and summaries of conventional and non-conventional documents, such as: books, theses, manuals, leaflets, congresses, periodicals and journals, generated in Brazil or, written by Brazilian authors and published in other countries, also including retrospective documents.

In order to assure broad search of primary studies, the controlled descriptors (search terms) were combined in different ways, using Boolean Operators OR and AND: Descriptors in Health Scienc (DeCs): (Quality of Life) AND (Work) AND (Family Relations OR Family Relation OR Family Relationship); and in the Medical Subject Headings (MeSH): (Quality of Life OR Life Qualities OR Life Quality) AND (work) AND (Family Relations OR Family Relation OR Family 
Relationships OR Family Dynamics OR Family Dynamic OR Family Relationship).

For these surveys, librarians assisted in the elaboration of the search strategy and in the bibliographic survey.

For the systematization of data, we developed a collection tool with the data related to the authors and publications, dividing in two important steps to better deepen the subject: 1) survey of all articles that included the interactions between QWL and family relations and 2) survey of all articles that include any of the items that make up the family functionality, as described in the family APGAR, and verify how they interfere in QWL.

Therefore, in the first step, the criteria of inclusion adopted were: available articles related to the research object, in Portuguese, English or Spanish, originated from national and international journals, indexed in the referred databases from 2011 to March 2016. As articles exclusion criteria the following topics were adopted: informal workers, instrument validation, disease-related quality of life, non-work quality of life. A total of 1,154 articles were found in the databases, of which 83 were established as a prior analysis body according to the flow chart of Figure 1.

Having all the articles resulting from the first step that contemplated the relations established between QWL and family relations, it was verified the absence of works using the family APGAR, or even that included all the items that make up the family functionality, according to the reference used (CFAM). In the second phase, to re-analyze the 83 articles, the new inclusion criteria adopted were: available articles related to the research subject, in Portuguese, English or Spanish, originated from national and international journals, indexed in the referred databases from 2011 to March 2016, which comprised at least one of the items considered for the study of family functionality, 13 articles being established as final analysis body as shown in Figure 1.
Figure 1: Flowchart of study selection.

\begin{tabular}{|c|c|c|c|c|c|}
\hline \multicolumn{6}{|c|}{ CAPES = 1106} \\
\hline $\begin{array}{l}\text { SICELO } \\
=0\end{array}$ & $\begin{array}{c}\text { CINAHL } \\
=38\end{array}$ & $\begin{array}{c}\text { EMBASE } \\
=125\end{array}$ & $\begin{array}{l}\text { SCOPUS } \\
=245\end{array}$ & $\begin{array}{l}\text { Web of } \\
\text { Science } \\
=404\end{array}$ & $\begin{array}{l}\text { PUBMED } \\
=294\end{array}$ \\
\hline
\end{tabular}

BIREME $=48$

\begin{tabular}{c|c|c|c}
$\begin{array}{c}\text { Medline } \\
=28\end{array}$ & $\begin{array}{c}\text { Lilacs } \\
=13\end{array}$ & $\begin{array}{c}\text { Index Psicologia PTC } \\
=4\end{array}$ & $\begin{array}{c}\text { BDENF- } \\
\text { Nursing }=3\end{array}$
\end{tabular}

Total Initial Sample: 1.154

Excluded studies First analysis (title and summary) Total: 917

excluded by inclusion and exclusion criteria.

Doubled studies excluded

Total: 66

Paid or not found studies and articles

Total: 23

Excluded studies Second Analysis (full text) Total: 65

excluded by inclusion and exclusion criteria.

Previous final sample

First Phase Total: 83

Excluded Studies

Total: 70

excluded because did not comprised any of the family functionality items

Final Sample Second Phase

Total: 13

\section{Results}

The articles, which made up the final previous sample from the first phase, are distributed per publication year according to Table 1, being the biggest prevalence in 2014 with a quarter of the body of the sample.

The articles selected in the first phase contemplate the world scenario as the places where the researches were developed can be verified in Table 2 . 
Table 1. Distribution per year of publication.

\begin{tabular}{|c|c|c|}
\hline Year & Frequency & $\%$ \\
\hline 2011 & 8 & 10 \\
\hline 2012 & 18 & 22 \\
\hline 2013 & 14 & 17 \\
\hline 2014 & 21 & 25 \\
\hline 2015 & 16 & 19 \\
\hline 2016 & 6 & 7 \\
\hline Total & 83 & 100 \\
\hline
\end{tabular}

Table 2. Distribution of publication per study place.

\begin{tabular}{|l|c|l|l|}
\hline \multicolumn{1}{|c|}{ Country } & $\mathbf{n}$ & \multicolumn{1}{c|}{ Country } & $\mathbf{n}$ \\
\hline USA & 17 & Turkey & 2 \\
\hline Brazil & 9 & Germany & 1 \\
\hline Australia & 8 & Austria & 1 \\
\hline Multi * & 7 & Finland & 1 \\
\hline China & 6 & France & 1 \\
\hline Poland & 5 & Iran & 1 \\
\hline Canada & 4 & Japan & 1 \\
\hline Spain & 3 & United Kingdom & 1 \\
\hline Italy & 3 & Czec Republic & 1 \\
\hline New Zealand & 3 & Slovenia & 1 \\
\hline Taiwan & 3 & Sweden & 1 \\
\hline India & 2 & Switzerland & 1 \\
*: multicenter studies that include researches in more than one country
\end{tabular}

Table 3. Distribution of publication per type of study.

\begin{tabular}{|l|c|c|}
\hline \multicolumn{1}{|c|}{ Type of research } & $\mathbf{n}$ & $\%$ \\
\hline Quantitative & 69 & 83.2 \\
\hline Qualitative & 10 & 12.0 \\
\hline Development of theoretical model & 1 & 1.2 \\
\hline Quanti-quali & 1 & 1.2 \\
\hline Opinion article & 1 & 1.2 \\
\hline Systematic review & 1 & 1.2 \\
\hline Total & 83 & 100.0 \\
\hline
\end{tabular}

As demonstrated in Table 3, according to the type of research, at the end of the study phase, we observed the prevalence of the quantitative researches (83\%).

It is possible to observe that the theme is comprehensive and multidisciplinary, by analyzing the distribution of the articles according to the themes addressed by the journals in which the articles of the first phase were published, according to Table 4.

Table 4. Distribution of publication from the first phase per journal theme.

\begin{tabular}{|l|c|c|}
\hline \multicolumn{1}{|c|}{ Area } & $\mathbf{n}$ & $\%$ \\
\hline Medicine and biological sciences & 18 & 22 \\
\hline Psychology and psychiatry & 16 & 20 \\
\hline Management & 12 & 14 \\
\hline Social sciences & 9 & 11 \\
\hline Health - several & 8 & 10 \\
\hline Public Health & 5 & 6 \\
\hline Nursing & 5 & 6 \\
\hline Work & 4 & 5 \\
\hline Quality of life & 3 & 3 \\
\hline Child and family & 2 & 2 \\
\hline Interdisciplinary & 1 & 1 \\
\hline Total & 83 & 100 \\
\hline
\end{tabular}

Table 5. Distribution of publication from the first phase per themes covered.

\begin{tabular}{|l|c|c|}
\hline \multicolumn{1}{|c|}{ Theme } & $\mathbf{n}$ & $\%$ \\
\hline Conflicts and balance & 27 & 33 \\
\hline Health & 15 & 18 \\
\hline Enrichment & 11 & 13 \\
\hline Influence of Work in the family & 10 & 12 \\
\hline Diagnosis & 9 & 11 \\
\hline Concepts and dimensions & 6 & 7 \\
\hline Influence of the Family in the work & 4 & 5 \\
\hline Family functionality & 1 & 1 \\
\hline Total & 83 & 100 \\
\hline
\end{tabular}

Among the studies reviewed in the first phase of this work, after broad reading of the full texts, we found researches that seek to interpret the interactions between the QWL and the family of the worker. In Table 5 we quantified the articles included in the review, per theme, under the perspectives outlined by the authors.

In the second phase of the study, it was sought to interpret the works found, from the point of view of family functionality, and few papers included the items that make up the family APGAR, as shown in Table 6 below: 
Through the Table 6 it can be observed that there is no consensus regarding to the direct or indirect influence of the family, their intentions or to their functionality in the labour environment and, consequently, in the QWL.

Table 6. Relation of articles resulting from the second phase.

\begin{tabular}{|c|c|c|c|c|c|c|c|}
\hline Seq & Article & $\begin{array}{l}\text { First } \\
\text { author }\end{array}$ & Population & Study object & $\begin{array}{l}\text { Identified } \\
\text { functional } \\
\text { item } \\
\text { (APGAR) }\end{array}$ & $\begin{array}{l}\text { Interaction of the family } \\
\text { functionality with the QWL }\end{array}$ & $\begin{array}{l}\text { Does } \\
\text { family } \\
\text { influence } \\
\text { the QWL? }\end{array}$ \\
\hline 1 & $\begin{array}{l}\text { Influences of } \\
\text { Work-Family } \\
\text { Interface } \\
\text { on Job and Life } \\
\text { Satisfaction }\end{array}$ & Simone S & $\begin{array}{l}427 \text { Italy public } \\
\text { administration } \\
\text { workers }\end{array}$ & $\begin{array}{l}\text { To test a model that } \\
\text { includes positive } \\
\text { interactions between work } \\
\text { and family as predictors } \\
\text { of satisfaction with work } \\
\text { and the life. It examined } \\
\text { the role of some potential } \\
\text { moderators (organizational } \\
\text { support, family support } \\
\text { and engagement at work) } \\
\text { of these relations. }\end{array}$ & Attention & $\begin{array}{l}\text { The factors involved in the } \\
\text { work-family interactions directly } \\
\text { and indirectly influence the } \\
\text { satisfaction with life, work and } \\
\text { the commitment to work. The } \\
\text { influence of the interface family- } \\
\text { work in the satisfaction with life } \\
\text { occurs in a lower level than the } \\
\text { interface work-family influence in } \\
\text { the satisfaction in work. }\end{array}$ & Yes \\
\hline 2 & $\begin{array}{l}\text { Burnout and } \\
\text { demographic } \\
\text { characteristics } \\
\text { of workers } \\
\text { experiencing } \\
\text { different types } \\
\text { of work-home } \\
\text { interaction }\end{array}$ & Merecz D & $\begin{array}{l}533 \text { Polish } \\
\text { citizens } \\
\text { with several } \\
\text { professions }\end{array}$ & $\begin{array}{l}\text { To explore the } \\
\text { configurations of positive } \\
\text { and negative interactions } \\
\text { between work and family } \\
\text { and its relation with the } \\
\text { burnout and demographic } \\
\text { characteristics }\end{array}$ & Time & $\begin{array}{l}\text { The various interactions (positive } \\
\text { or negative) may reflect cultural } \\
\text { differences between groups, } \\
\text { expressing different attitudes } \\
\text { in work and family life, besides } \\
\text { the different values attributed } \\
\text { to people to manage the roles } \\
\text { associated to these two areas. } \\
\text { The impact and the direction } \\
\text { of the interactions may depend } \\
\text { on the domain that is the most } \\
\text { important to each individual } \\
\text { (work or family). In the studied } \\
\text { sample, people did not allow that } \\
\text { the private problems interfered } \\
\text { negatively in the occupational } \\
\text { life, in an attitude of protection } \\
\text { to the use of the private sphere. } \\
\text { People with positive interactions } \\
\text { family-work reported high } \\
\text { professional efficiency. }\end{array}$ & No \\
\hline 3 & $\begin{array}{l}\text { Stress amongst } \\
\text { nurses working } \\
\text { in a healthcare } \\
\text { telephone- } \\
\text { advice service: } \\
\text { relationship } \\
\text { with job } \\
\text { satisfaction, } \\
\text { intention to } \\
\text { leave, sickness } \\
\text { absence, and } \\
\text { performance }\end{array}$ & $\begin{array}{c}\text { Farquharson } \\
\text { B }\end{array}$ & $\begin{array}{l}152 \text { Nurses from } \\
\text { Scotland }\end{array}$ & $\begin{array}{l}\text { It was assessed the stress } \\
\text { among workers, including } \\
\text { indicators of satisfaction at } \\
\text { work and conflicts work- } \\
\text { family. }\end{array}$ & $\begin{array}{l}\text { Discussion } \\
\text { and } \\
\text { problems } \\
\text { solving. }\end{array}$ & $\begin{array}{l}\text { The stress depends on the } \\
\text { resources acquired to face the } \\
\text { competition of the work and } \\
\text { family demands, taking into } \\
\text { consideration that at work } \\
\text { there is less tolerance about } \\
\text { bad functioning of the person. } \\
\text { "Family-interfering at work" } \\
\text { did not find significance to } \\
\text { be considerate as predictor of } \\
\text { satisfaction at work and the } \\
\text { intention of leaving the current } \\
\text { job. }\end{array}$ & No \\
\hline
\end{tabular}




\begin{tabular}{|l|l|} 
Seq & \multicolumn{1}{c|}{ Article } \\
\hline 4 & $\begin{array}{l}\text { Beyond the body: A } \\
\text { systematic review } \\
\text { of the nonphysical } \\
\text { effects of a surgical } \\
\text { career }\end{array}$ \\
\hline
\end{tabular}

5 The relationship between work-family enrichment and nurse turnover

6 Cancer surgeons' distress and well-being, Il: modifiable factors and the potential for organizational interventions

7 Purpose in life and work-related stress in mariners. Mediating role of quality of marriage bonds and perceived anxiety

\section{Guest RS \\ 72} oncological

surgeons

from USA

It examines modifiable workplace

factors and other stress factors

associated with the burnout,

psychiatric morbidity, and low quality of life.

Peplińska A 210 mariners It verifies the relation between the from Poland stress perceived by the workers and their life-purpose sense, altogether with the mediator role of quality levels of the marriage and anxiety.

\section{Identified}

functional

item

(APGAR)

Discussion

and problem

solving.

Enrichment family-work nor to the turnover. The enrichment family-work is positively related to the work satisfaction and to the professional commitment. The professional commitment is mediator of the work-family enrichment.

Marital

problems.

Workers stressed by marital problems or by the work-family balance are more likely to the burnout. The time seems to be a specific stress factor to the family, being associated to the burnout. The relationship with the wife and the time available for the family are strongly associated negatively with the quality of the workers' life.

Threats related to the profession practiced and the determination of high levels of perceived stress are associated with low levels of satisfaction with married life (family).High levels of satisfaction with married quality life are the necessary condition to the neutralization of the negative effects of stress. This neutralization occurs as a type of regenerations of each one's resources, by the compensation of what have been sacrificed for the professional life of each one or by bringing important emotional resources. Despite the low levels of satisfaction with the marriage, it may still neutralize the stress

\section{Does}

family influence the QWL?

consistency

Both genders were more likely to solve conflicts work-family in a way that served both personal and professional responsibilities. The studies presented inconsistency regard to satisfaction at work when related with the marital status and children. 
Seq

\section{Article}

First author Population

Study object

Identified

functional

item

(APGAR)

8 Varying

Responsibilities

Across Job \& Home

Domains and

Employee Well Being

9 An Investigation into the Relationship

between Hospitality Employees' Work-

Family Conflicts

and Their Leisure

Intentions

10 Commitment to life roles and work-family conflict among

managers in a postsocialist country
Rasool H 291 workers To study the effect of the facilitation in the service and conflict work-family in the sector satisfaction of the employees

Zhao X 271 complete

service

hotels

workers in

China

To analyze what the impacts of interface work-family and interface family-work over the work tension and the relaxation intension are.

\section{Family}

satisfaction.

Mihelič KK $413 \quad$ To examine antecedents and results organizations of work-family and the work-family managers conflict between managers in a prefrom socialist country.

Marital care, time.
If the family-work levels of interference are high, persons might not be satisfied

with their house, but may be satisfied with their job. No relation between the workdifferent phenomenon if compared to the work satisfaction. The negative relation of work-family facilitation with the satisfaction at work and facilitation family-work satisfaction at home, which was inconsistent in previous studies, was observed.

Satisfaction The levels of interface family-work are lower than the interface work-family. Interface family-work has positive effect on the work tension. Interface work-family and interface family-work may have different patterns of relation with the intention of relaxing and social. The workers' family boundaries are more permeable than those of work, that is, their job demands are more likely to interfere in the family life than their family life invade their labour responsibilities. When excessive job demands interrupt family obligations, the individuals seek for relaxation. But when the family interfere with the work the workers redouble their effort at work, perhaps for fear that satisfaction in social activities and relaxation will prevent them from achieving satisfactory results at work. Leisure activities, by itself, do not solve problems of work-family conflicts. satisfaction. family-work conflicts related to time are associated to the rising of satisfaction Support, Love, in the career, but not the ones related to efforts. The workers avoid transmitting symptoms of tension caused by family demands to the professional environment. They should show demonstrate capability to find different ways and strategies to face conflicts between person and professional life. In Slovenia, to solve conflicts work-family is considered a personal obligation. Recognizing problems in family may harm your image toward the coworkers about your competency or influence negatively on possible opportunities of advancement in career. Marital commitment influence in the satisfaction with the marriage, but not related to the conflicts FW. The engagement in the family role affects the individual functioning more positively than negatively by conducting for satisfaction more directly than the rise of conflicts. The culture questions must be assessed such as the woman role in the society.
Does

family influence the QWL? 


\begin{tabular}{|c|c|c|c|c|c|c|c|}
\hline Seq & Article & $\begin{array}{l}\text { First } \\
\text { author }\end{array}$ & Population & Study object & $\begin{array}{l}\text { Identified } \\
\text { functional } \\
\text { item } \\
\text { (APGAR) }\end{array}$ & $\begin{array}{l}\text { Interaction of the family functionality } \\
\text { with the QWL }\end{array}$ & $\begin{array}{c}\text { Does } \\
\text { family } \\
\text { influence the } \\
\text { QWL? }\end{array}$ \\
\hline 11 & $\begin{array}{l}\text { Attachment } \\
\text { Styles, } \\
\text { Relationship } \\
\text { Satisfaction, } \\
\text { and Well- } \\
\text { Being in } \\
\text { Working } \\
\text { Women }\end{array}$ & Towler AJ & $\begin{array}{l}209 \text { several } \\
\text { women } \\
\text { from USA } \\
\text { organizations }\end{array}$ & $\begin{array}{l}\text { To propose and } \\
\text { test a model } \\
\text { that associated } \\
\text { styles of } \\
\text { relationship of } \\
\text { women, quality } \\
\text { of the intimate } \\
\text { relationship, } \\
\text { relationship } \\
\text { with the } \\
\text { supervisor, at } \\
\text { workplace and } \\
\text { well being. }\end{array}$ & $\begin{array}{l}\text { Consensus, } \\
\text { satisfaction } \\
\text { and cohesion } \\
\text { between } \\
\text { partners. }\end{array}$ & $\begin{array}{l}\text { The several styles of relationship differ } \\
\text { according to each individual. Styles of } \\
\text { relationship are associated with family } \\
\text { satisfaction. Women with secure style } \\
\text { are more likely to have relationship more } \\
\text { satisfying at home, at work and with the } \\
\text { supervisor, taking into account their strong } \\
\text { social skills that allow them to function } \\
\text { effectively in both environments (family and } \\
\text { work). High quality of the family relationships } \\
\text { is positively associated with the satisfaction } \\
\text { at work and negatively with conflicts at the } \\
\text { labour environment. }\end{array}$ & Yes \\
\hline 12 & $\begin{array}{l}\text { Factors } \\
\text { influencing } \\
\text { the levels } \\
\text { of work } \\
\text { engagement } \\
\text { in physicians } \\
\text { from Poland, } \\
\text { Serbia and } \\
\text { Bulgaria }\end{array}$ & $\begin{array}{l}\text { Wilczyński } \\
\text { KM }\end{array}$ & $\begin{array}{l}417 \\
\text { physicians } \\
\text { from Poland, } \\
\text { Serbia and } \\
\text { Bulgaria }\end{array}$ & $\begin{array}{l}\text { To assess the } \\
\text { influence of } \\
\text { the family } \\
\text { life and other } \\
\text { factors about } \\
\text { the levels of } \\
\text { engagement of } \\
\text { work and risk } \\
\text { of depression }\end{array}$ & $\begin{array}{l}* * * \text { not } \\
\text { identified }\end{array}$ & $\begin{array}{l}\text { The family life seems to have little or no } \\
\text { influence over their involvement in work and } \\
\text { the risk of burnout. The negative influence } \\
\text { of the work at life might increase the risk of } \\
\text { depression, and this effect is not susceptible } \\
\text { to any positive or negative interaction of } \\
\text { family life with work. The relation between } \\
\text { the family and work life has a very bad } \\
\text { effect on the level of work engagement. The } \\
\text { family life may act just as a protection factor. } \\
\text { Contrary to the view that high demands for } \\
\text { work and lack of adequate rest can cause } \\
\text { reduced engagement, it seems that if family } \\
\text { life prevents effective leisure and increases } \\
\text { demands, the worker can "escape" in his } \\
\text { duties, which is seen as a slight increase in } \\
\text { engagement at work. }\end{array}$ & No \\
\hline 13 & $\begin{array}{l}\text { Quality of } \\
\text { work life } \\
\text { and family } \\
\text { functioning } \\
\text { in faculty } \\
\text { members of } \\
\text { Islamic Azad } \\
\text { University }\end{array}$ & Bonab MB & $\begin{array}{l}310 \\
\text { University } \\
\text { professors in } \\
\text { Iran }\end{array}$ & $\begin{array}{l}\text { Investigate } \\
\text { if there is a } \\
\text { relationship } \\
\text { between what } \\
\text { happens in } \\
\text { the work and } \\
\text { the family } \\
\text { environment. } \\
\text { If the work } \\
\text { environment } \\
\text { can be } \\
\text { extended to } \\
\text { non-work } \\
\text { environment. }\end{array}$ & $\begin{array}{l}\text { Problems } \\
\text { solving, } \\
\text { affection. }\end{array}$ & $\begin{array}{l}\text { There is a significant relation between the } \\
\text { professor attitudes, depending on their } \\
\text { university degree and the QWL and family } \\
\text { functioning. The family functioning influence } \\
\text { is greater on the QWL for the professors } \\
\text { who are members of small branches of the } \\
\text { university. There are significant differences } \\
\text { among the four interviewed groups in terms } \\
\text { of attitudes towards "family functioning" } \\
\text { with regard to the comparisons of groups } \\
\text { of professors from different branches of the } \\
\text { university }\end{array}$ & $\begin{array}{l}\text { Yes, depending } \\
\text { on the } \\
\text { investigated } \\
\text { group (partial) }\end{array}$ \\
\hline
\end{tabular}




\section{Discussion}

The objective of this study was to identify the main interactions between QWL and the family environment and to verify if the family functionality can influence the levels of QWL, composing the body of knowledge production in the literature in the last five years.

\section{The interactions between the QWL and family}

Initially, the interactions which emerged from the present study were grouped in eight thematic axes, according to the analysis and perspectives of the researcher, namely: a) Concepts and Dimensions; b) Conflicts and Balance, c) Health, d) Roles Enrichment, e) Influence of Work in the Family, f) Diagnosis, g) Influence of the Family on Work and h) Family Functionality.

In the grouping of Concepts and Dimensions are the articles that describe and discuss the fundamental concepts of QWL, its dimensions and domains in the worker's life that must comprehend those related to the subjective well-being, always including the family relations in the referred contexts [13-18]. Despite the divergence among researchers about how best to conceptualize $\mathrm{QWL}$, the studies offer new theoretical models or at least comprehensive ways of analyzing the existing theories. In all of them, however, there is congruence in the need to expand the QWL, mainly covering family relationships and pointing out the need for studies in this important relationship and in the different roles that human represents in the various environments in which they work.

In the topic Conflicts and Balance all the researches that had as objective to describe the conflicts way were grouped, being the most cited: conflicts work-family and conflicts family-work. On the other hand, we also include those works on balance in these conflictual relations. Our studies revealed that there is a high number of researches with the objective of analyzing the different forms of conflicts and the importance of to establish the balance to avoid these conflicts [19-45].

The topic Health covers the studies with focus on the work health, which analyzes the relations between the QWL and inserts it in family contexts. The mental diseases, including depression and suicide intentions and, mainly the Burnout syndrome are reported. The family, in these studies, is treated usually as collection tool item and emotional support source. High levels of prevalence of the Burnout syndrome among the workers seem to have led many researchers of the health area to analyze this disease, relating it to the various forms of family environment. Reported in at least 15 studies, the Burnout syndrome is known in the medicine field as occupational disease, usually triggered in stressful work environments [46-60].

In the group of the topic Roles Enrichment all the articles report the experiences, considered positive, and the benefits of the work-family interface, including the established relationship forms. Opportunity to add knowledge, flexibility and support at work, work experiences, financial benefits, satisfaction, work itself and conflict itself are examples of elements of enrichment at work. As for the generative elements of family enrichment, we can cite: family values, family experiences, family relationships and family support. Such elements may be used to improve the functioning of a domain in other life domains, such as work and family environment, and may occur in both directions [61-71].

The studies grouped in the topic Influence of Work in Family included those who main objective were to describe the various forms of influence of work in family, positive and especially negative, such as work hours, shifts, management forms and leadership in the work environment. Yet, in the topic Influence of Family on Work were inserted the studies which describe, somehow, the family influencing the worker or their labour environment. In these axes, 14 articles present the various influences of one domain on the other. Most of them (10) re- 
port the effects of work in the family environment, mainly related to schedules and shifts, forms of management and leadership [72-81]. On the other hand, only four describe some forms of influence of the family on work. The found ones are related, especially, to the social support role performed by the family with the worker, through the emotional support [82]. We also found reports about the fact that the family would be a stressful factor for the worker, pointing it as a negative effect in these interactions [83-85].

The researches that make up the theme Diagnosis are those which bring the evaluation of the QWL, also characterized as job or career satisfaction, in several populations of workers, whose collection instruments contemplated some dimension of family life, but without the deepening of these issues. A relative number of studies (9) bring the diagnosis of quality of life of workers that include indicators of family life. The populational diversity of workers and organizations found enriches the literature [86-94].

The group defined as Family Functionality was created to comprehend articles whose purpose was to investigate and to deepen in to the family relations, characterized by the way the family members relate to each other, and their interactions with the QWL, being found only one study in an Islamic university [95].

\section{The family functionality and their influence in the QWL}

Data from the present study revealed a lack of consensus about the existence of family influence on QWL, with studies showing positive interferences, other negative ones, in addition to those that report no relationship between these two environments.

The interactions presented in some studies on the enrichment of roles point to the positive relationship with job satisfaction and professional commitment. High quality of the family relationships was positively associated with satisfaction at work and negatively with the conflicts at work environment [68].
Studies including items on marital relationships report that workers stressed by marital problems, work-family (im) balance, or dissatisfaction with marital or family life, are more likely to exhaust and reduce their quality of life at work [52]. Marital satisfaction appears to have a significant influence on career satisfaction [64]. High levels of satisfaction of marital life quality seem to be the necessary condition to neutralize the negative effects of stress [72]. This neutralization occurs as a kind of regeneration of one's resources, compensation for what has been sacrificed for one's professional life, or for bringing in important emotional resources [72]. It was observed that, despite the low levels of satisfaction with the marriage, it still could neutralize the stress.

The Family-Work conflicts related to the time spent with the family are associated to the increase of satisfaction in the career, but not the ones related to effort. Workers avoid transmitting symptoms of tension caused by family demands to the professional environment, and must demonstrate the ability to find different ways and strategies to face conflicts between personal and professional life. Mainly for leadership and management functions, resolving work-family conflicts is considered a personal obligation. We also found that recognizing problems in the family could harm their image to their coworkers about their competencies or negatively influence on possible career advancement opportunities [64].

Most studies, however, point to a broader range of studies, and cultural issues such as the location of the population studied (rural, urban), work area, diverse ethnicities, the role of women in society, etc. should be considered. In this way, the psychological and behavioral issues should also be extended, once it seems to influence on the results. Individual personalities and the various relationship styles may reflect directly or indirectly, since these social skills are associated with family satisfaction and relationships with co-workers, supervisors, clients, or patients [65]. The various interactions (positive or negative) may reflect cultural differences between 
groups, expressing different attitudes at work and family life, as well as the different values attributed by people to manage the roles associated with these two areas. The impact and direction of interaction may depend on the domain that is most important to each individual (work or family) [58].

While some studies indicate that the commitment in the family role affects the individual functioning more positively than negatively (satisfaction versus conflicts) [64], others point out that the work may serve, inclusive, like an escape valve to the dissatisfaction in family environment [85]. Among the researches that did not find an association between the family environment and QWL, we observed that cultural issues can influence the responses. Depending on the population studied, workers may not allow the particular problems to interfere negatively in the occupational life, in an attitude of protection to the employment of the private sphere [58].

People with positive family-work interaction reported high professional efficiency, but not associated significantly to QWL, satisfaction with work or to the intention of leaving the current job [58].

If levels of family-work interference are high, individuals may not be satisfied with their home, but they may nonetheless be satisfied with their work. No relationship between work-family interference and family satisfaction reveals that family satisfaction may be a different phenomenon compared to job satisfaction [36]. In this sense, the limits of the family of workers seem to be more permeable than those of work, that is, their work demands are more likely to interfere with family life than their family life invades their work responsibilities [29].

We also found that when excessive work demands interrupt the family obligations, the individuals seek for relaxation. But when the family interferes with work the workers redouble their effort at work, perhaps for fear that satisfaction in social activities and relaxation will prevent them from achieving satisfactory results at work. Nevertheless, leisure activities by themselves cannot solve problems of work-family conflicts [29].
In relation to burnout, family life seems to have little or no influence on their involvement in the work and risk of the syndrome. The negative influence of work in family life may increase the risk of depression. However, this effect seems not to be susceptible to any positive or negative interaction of family life with work [85]. Stress in these studies depends on the resources acquired to face the competition of work and family demands, taking into account that at work there is less tolerance due to worse functioning of the individual [25].

The relation between family and work life has a very bad effect on the level of work engagement, and might act only as a protection factor. Contrary to the view that high demands for work and lack of adequate rest can cause engagement to be reduced, it seems that if family life prevents effective leisure and increases the demands, the worker can "escape" in his duties, which Is visible as a slight increase in work engagement [85].

We observed that a shortage of complete studies on the influence of the worker's family functionality on his quality work life impairs the interpretation of this important anthropological phenomenon for two reasons. Firstly, there is no consensus about the direct or indirect influence of the family, their interactions or their functionality in the work environment and, consequently, the QWL, which is in line with the systematic review Of Oskrochi on medical surgeons [53]. Second, due to the shortage of researches those seek QWL correlations and family functionality, in its most comprehensive form. Such findings lead us to conclude that family functionality should be better investigated in future researches.

\section{Conclusions}

Most studies that present relations between QWL and family aim, mainly, to study the conflicts between the family and work environment and their consequences to the workers and family. In occupational medicine, most researchers also study Burnout syndrome and other mental illnesses. Few papers 
discuss possible family influences on the worker or work environment and their results do not converge to a consensus in the literature. The scarcity of studies about family interactions and, especially, family functionality with QWL demonstrate the need for future research on these two aspects, aiming to deepen the understanding of these themes, to expand investigations and to enable the improvement of QWL in organizations and the integral satisfaction of workers.

\section{References}

1. Limongi-França $A C$. O que é qualidade de vida no trabalho? Breve percurso conceitual, histórico e projeções para a próxima década. In: Ferreira MC, Antloga C, Paschoal T. Ferreira RR. Qualidade de vida no trabalho: questões fundamentais e perspectivas de análise e intervenção. Brasília: Paralelo 15; 2013; 1:39-50

2. Bom Sucesso E. Olhares cruzados sobre a qualidade de vida no trabalho. In: Ferreira MC, Antloga C, Paschoal T, Ferreira RR. Qualidade de vida no trabalho: questões fundamentais e perspectivas de análise e intervenção. Brasília: Paralelo 15; 2013; 3:51-64

3. Stam M, Mioto RCT. Família e cuidado: uma leitura para além do óbvio. Ciênc Cuid Saúde. 2003; 2(2):161-8.

4. Yunes MAM Avaliação e intervenção na família: visão geral. In: Wright LM, Leahey M. Enfermeiras e famílias: um guia para avaliação e intervenção na família. São Paulo: Roca; 2009. Cap. 1.

5. Smilkstein $\mathrm{G}$. The family APGAR a proposal for a family function test and its use by physicians. J Fam Pract. 1978; 6(6):1231-9.

6. Duarte YAO. Família: rede de suporte ou fator estressor: a ótica de idosos e cuidadores familiares [tese]. São Paulo (SP): Universidade de São Paulo, Programa de Pós-Graduação em Enfermagem; 2001.

7. Souza FGM, Figueiredo MCAB, Erdmann AL. Instruments for family assessment and intervention: a descriptive study. Rev Pesqui Saúde. 2010; 11(1):60-3.

8. Suarez Cuba MA, Alcala Espinoza M. Apgar familiar: una herramienta para detectar disfunción familiar. Rev Méd La Paz. 2014; 20(1):53-7.

9. Mendes KDS, Silveira RCCP, Galvão CM. Revisão integrativa: método de pesquisa para a incorporação de evidencias na saúde e na enfermagem. Texto Contexto Enferm. 2008; 17(4):758-64.

10. Ganong LH. Integrative reviews of nursing research. Res Nurs Health. 1987; 10(1):1-11.

11. Whittemore R. Combining evidence in nursing research: methods and implications. Nurs Res. 2005; 54(1):56-62.
12. Santos CM, Pimenta CAM, Nobre MRC. A estratégia pico para a construção da pergunta de pesquisa e busca de evidências. Rev Latino-am Enfermagem. 2007; 15(3):508-11.

13. Cooke GB, Donaghey J, Zeytinoglu IU. The nuanced nature of work quality: evidence from rural Newfoundland and Ireland. Hum Relat. 2013; 66(4):503-27.

14. Oliveira DB, Rangel R, Costenaro RGS, Gehlen MH, Quadros JS, Roso CC. Qualidade de vida: percepção de educadores de uma escola estadual do município de Santa Maria - Rio Grande do Sul. Rev Pesqui Cuid Fundam (Online). 2012; 4(3):2540-7.

15. Díaz-Chao Á, Ficapal-Cusí P, Torrent-Sellens J. Multidimensional determinants of perceived work quality: empirical evidence from Spain. Rev Int Sociol [Internet]. 2015 [cited 2016 Dec 1]; 73(1). Available from: http://revintsociologia.revistas.csic.es/ index.php/ revintsociologia/article/viewArticle/612/647.

16. Bracarense CF, Costa NS, Duarte JMG, Ferreira MBG, Simões ALS. Qualidade de vida no trabalho: discurso dos profissionais da Estratégia Saúde da Família. Esc Anna Nery. 2015; 19(4):5428.

17. Díaz-Chao A, Ficapal-Cusí P, Torrent-Sellens J. Economic crisis and job quality in Spain: a multi-dimensional and micro-data empirical approach. J Soc Indic Res. 2016; 125:613. doi: 10.1007/ s11205-014-0850-0.

18. Gurková E, Haroková S, Džuka J, Žiaková K. Job satisfaction and subjective well-being among Czech nurses. Int J Nurs Pract. 2013; 20(2):194-203.

19. Nelson SA. Affective commitment of generational cohorts of Brazilian nurses. Int J Manpow. 2012; 33(7):804-21.

20. Janzen BL, Kelly IW. Psychological distress among employed fathers: associations with family structure, work quality, and the work-family interface. Am J Mens Health. 2012; 6(4):294-302.

21. Lin JH, Wong JY, Ho CH. The role of work-to-leisure conflict in promoting frontline employees' leisure satisfaction examining the job demand-control-support model. Int J Contemp Hosp Manag. 2015; 27(7):1539-55.

22. Wong JY, Lin JH, Liu SH, Wan TH. Fireman's job stress: integrating work/non-work conflict with Job Demand-Control-Support model European. Rev Eur Appl Psychol. 2014; 64(2):83-91.

23. Lallukka T, Ferrie JE, Kivimäki M, Shipley MJ, Sekine M, Tatsuse $T$, et al. Conflicts between work and family life and subsequent sleep problems among employees from Finland, Britain, and Japan. Int J Behav Med. 2014; 21(2):310-8.

24. Singh KA, Spencer AJ, Roberts-Thomson KF, Brennan DS. Workfamily conflict and oral and general health-related quality of life. Int J Behav Med. 2015; 22(4):489-97. doi: 10.1007/s12529-0149454-y. 
25. Farquharson $B$, Allan J, Johnston $D$, Johnston $M$, Choudhary $C$, Jones $M$. Stress amongst nurses working in a healthcare telephone-advice service: relationship with job satisfaction, intention to leave, sickness absence, and performance. J Adv Nurs. 2012; 68(7):1624-35.

26. Dyrbye LN, Sotile W, Boone S, West CP, Tan L, Satele D, et al. A survey of U.S. physicians and their partners regarding the impact of work-home conflict. J Gen Intern Med. 2014; 29(1):155-61.

27. Lee DH, Lin Z. Antecedents of work-family conflict and the moderating effect of perceived organizational support in China. Asian Soc Sci. 2013; 9(3):28-39.

28. Cheung C, Wang L, Chan RK. Differential impacts of stressors on sense of belonging. Soc Indic Res. 2013; 113(1):277-97.

29. Zhao X, Qu H, Liu J. An investigation into the relationship between hospitality employees' work-family conflicts and their leisure intentions. Cornell Hosp Q. 2014; 20(10):1-14.

30. Beutell NJ, Schneer JA. Work-family conflict and synergy among Hispanics. J Manag Psychol. 2014; 29(6):705-35.

31. Karatepe OM, Demir E. Linking core self-evaluations and work engagement to work-family facilitation. A study in the industry. Int J Contemp Hosp Manag. 2014; 26(2):307-23.

32. Winefield HR, Boyd C, Winefield AH. Work-family conflict and well-being in university employees. J Psychol. 2014; 148(6):68397.

33. Jiang $\mathrm{H}$. A model of work-life conflict and quality of employeeorganization relationships (EORs): transformational leadership, procedural justice, and family-supportive workplace initiatives. Public Relat Rev. 2012; 38(2):231-45.

34. Shimazu A, Demerouti E, Bakker AB, Shimada K, Kawakami $\mathrm{N}$. Workaholism and well-being among Japanese dual-earner couples: a spillover-crossover perspective. Soc Sci Med. 2011; 73(3):399-409.

35. Cooklin AR, Westrupp E, Strazdins L, Giallo R, Martin A, Nicholson JM. Mothers' work-family conflict and enrichment: associations with parenting quality and couple relationship. Child Care Health Dev. 2015; 41(2):266-77.

36. Rasool H, Nasir ZM. Varying responsibilities across job \& home domains and employee well being. Appl Res Qual Life. 2013; 8(4):413-25.

37. Mao Y, Kwan HK, Chiu RK, Zhang $X$. The impact of mentorship quality on mentors' personal learning and work-family interface. Asia Pac J Hum Res. 2015; 54(1):79-97.

38. Haslam DM, Patrick P, Kirby JN. Giving voice to working mothers: a consumer informed study to program design for working mothers. J Child Fam Stud. 2015; 24(8):2463-73.

39. Soma KJ, Thomson WM, Morgaine KC, Harding WJ. A qualitative investigation of specialist orthodontists in New Zealand: part 2. Orthodontists' working lives and work-life balance. Aust Orthod J. 2012; 28(2):170-80.
40. Odle-Dusseau HN, Britt TW, Bobko F. Work-family balance, well-being, and organizational outcomes: investigating actual versus desired work/family time discrepancies. J Bus Psychol. 2012; 27:331-43.

41. Lu J, Tjosvold D, Shi K, Wang B. Developing work-family balance through conflict management. Asian J Soc Psychol. 2012; 15:7788.

42. Gächter M, Savage DA, Torgler B. Retaining the thin blue line: what shapes workers' intentions not to quit the current work environment. Int J Soc Econ. 2013; 40(5):479-503.

43. Bianchi SM. Changing families, changing workplaces. Future Child. 2011; 21(2):15-36.

44. Mauno S, Cuyper ND, Kinnunen U, Ruokolainen M, Rantanen J, Mäkikangas A. The prospective effects of work-family conflict and enrichment on job exhaustion and turnover intentions: comparing long-term temporary vs. permanent workers across three waves. Work Stress. 2015; 29(1):75-94.

45. Hagga AK, Geser W, Ostermann H, Schusterschitz C. Relation of work family conflict and role quality on depressive symptoms in mothers. J Public Health. 2012; 20(2):661-71.

46. Gallavan DB, Newman JL. Predictors of burnout among correctional mental health professionals. Psychol Serv. 2013; 10(1):115-22

47. Baxter S, Sanderson K, Venn A, Otahal P, Palmer AJ. Construct validity of SF-6D health state utility values in an employed population. Qual Life Res. 2015; 24(4):851-70.

48. McLean KN. Mental health and well-being in resident mine workers: out of the fly-in fly-out box. Aust J Rural Health. 2012; 20(3):126-30.

49. Compton MT, Frank E. Mental health concerns among Canadian physicians: results from the 2007-2008 Canadian Physician Health Study. Compr Psychiatry. 2011; 52(5):542-7.

50. Shanafelt TD, Boone S, Tan L, Dyrbye LN, Sotile W, Satele D, et al. Burnout and satisfaction with work-life balance among us physicians relative to the general us population. Arch Intern Med. 2012; 172(18):1377-85.

51. Śliwiński Z, Starczyńska M, Kotela I, Kowalski T, Kryś-Noszczyk K, Lietz-Kijak D, et al. Life satisfaction and risk of burnout among men and women working as physiotherapists. Int J Occup Med Environ Health. 2014; 27(3):400-12.

52. Guest RS, Baser R, Li Y, Scardino PT, Brown AE, Kissane DW. Cancer surgeons' distress and well-being, II: modifiable factors and the potential for organizational interventions. Ann Surg Oncol. 2011; 18(5):1236-42.

53. Oskrochi Y, Maruthappu M, Henriksson M, Davies AH, Shalhoub J. Beyond the body: a systematic review of the nonphysical effects of a surgical career. Surgery. 2016; 159(2):650-64.

54. Woodhead EL, Northrop L, Edelstein B. Stress, social support, and Burnout among long-term care nursing staff. J Appl Gerontol. 2016; 35(1):84-105. doi: 10.1177/0733464814542465 
55. Tabeleao VP, Tomasi E, Neves SF. Quality of life and burnout among public high school and primary school teachers in Southern Brazil. Cad Saúde Pública. 2011; 27(12):2401-8.

56. Bouzas JAC, Fernández ML, Castro YR, Garrido JMF. Hardiness, quality of life and burnout among sociosanitary professionals in gerontological centers. Salud(i) ciência. 2013; 19(7):599-606.

57. McAbee JH, Ragel BT, McCartney S, Jones GM, Michael LM, DeCuypere $M$, et al. Factors associated with career satisfaction and burnout among US neurosurgeons: results of a nationwide survey. J Neurosurg. 2015; 123(1):161-73.

58. Merecz D, Andysz A. Burnout and demographic characteristics of workers experiencing different types of work-home interaction. Int J Occup Med Environ Health. 2014; 27(6):933-49.

59. Mather L, Blom V, Svedberg P. Stressful and traumatic life events are associated with Burnout-A Cross-Sectional Twin Study. Int J Behav Med. 2014; 21(6):899-907.

60. Śliwiński Z, Starczyńska M, Kotela I, Kowalski T, Kryś-Noszczyk K, Lietz-Kijak D, et al. Burnout among physiotherapists and length of service. Int J Occup Med Environ Health. 2014; 27(2):224-35.

61. Zhang $H$. Servant leadership, organizational identification, and work-to-family enrichment: the moderating role of work climate for sharing family concerns. Hum Res Manag. 2012; 51(5):74768.

62. Leach LS, Butterworth P. Psychosocial adversities at work are associated with poorer quality marriage-like relationships. J Popul Res. 2012; 29(4):351-72.

63. D'Affonseca SM, Cia F, Barham EJ. Trabalhadora feliz, mãe feliz? Condições de trabalho que influenciam na vida familiar. Psicol Argum. 2014; 32(76):129-38.

64. Mihelič KK. Commitment to life roles and work-family conflict among managers in a post-socialist country. Career Dev Int. 2014; 19(2):204-21

65. Towler AJ, Stuhlmacher AF. Attachment styles, relationship satisfaction, and well-being in working women. J Soc Psychol. 2013; 153(3):279-98

66. Abraham C, Russo M. The power of micro-moves in cultivating regardful relationships: implications for work-home enrichment and thriving. Hum Res Manag Rev. 2015; 26(2):112-24.

67. Jiang Z, Hu X. Knowledge sharing and life satisfaction: the roles of colleague relationships and gender. Soc Indic Res. 2016; 126(1):379-94.

68. Russo M, Buonocore F. The relationship between work-family enrichment and nurse turnover. J Manag Psychol. 2012; 27(3):216-36.

69. Jennings KS, Sinclair RR, Mohr CD. Who benefits from family support? Work schedule and family differences. J Occup Health Psychol. 2016; 21(1):51-64.
70. Culbertson SS, Mills M, Fullagar C. Work engagement and work-family facilitation: Making homes happier through positive affective spillover. Hum Relat. 2012; 65(9):1155-77.

71. Molino M, Ghislieri C, Cortese CG. When work enriches family-life: the mediational role of professional development opportunities. J Workplace Learn. 2013; 25(2):98-113.

72. Peplińska A, Jeżewska M, Leszczyńska I, Połomski P. Purpose in life and work-related stress in mariners. Mediating role of quality of marriage bonds and perceived anxiety. Int Marit Health. 2014; 65(2):87-92.

73. Torkington AM, Larkins S, Gupta TS. The psychosocial impacts of fly-in fly-out and drive-in drive-out mining on mining employees: a qualitative study. Aust J Rural Health. 2011; 19(3):135-41.

74. Turk M, Davas A, Tanik FA, Montgomery AJ. Organizational stressors, work-family interface and the role of gender in the hospital: experiences from Turkey. Br J Health Psychol. 2014; 19(2):442-58.

75. Oliveira ERA, Garcia AL, Gomes MJ, Bittar TO, Pereira AC. Gender and perceived quality of life - research with professors from the health area. Ciênc Saúde Colet. 2012; 17(3):741-7.

76. Emmett BM, Dovey SM, Wheeler BJ. After-hours on-call: the effect on paediatricians' spouses and families. J Paediatr Child Health. 2013; 49(3): 246-50.

77. Lawson KM, Davis KD, McHale SM, Hammer LB, Buxton OM. Daily positive spillover and crossover from mothers' work to youth health. J Fam Psychol. 2014; 28(6):897-907.

78. Clendon J, Walker L. Nurses aged over 50 years and their experiences of shift work. J Nurs Manag. 2013; 21(7):903-13

79. Kennedy EH, Krahn H, Krogman HT. Downshifting: an exploration of motivations, quality of life, and environmental practices. Sociol Forum. 2013; 28(4):764-83.

80. Strzemecka J, Pencuła M, Owoc A, Szot W, Strzemecka E, Jabłoński $\mathrm{M}$, et al. The factor harmful to the quality of human life - shift-work. Ann Agric Environ Med. 2013; 20(2):298-300.

81. Bagger J, Li A. How does supervisory family support influence employees' attitudes and behaviors? A social exchange perspective. J Manag. 2014; 40(4):1123-50.

82. Ferguson M, Carlson D, Kacmar KM, Halbesleben JR. The supportive spouse at work: does being work-linked help? J Occup Health Psychol. 2016; 21(1):37-50.

83. Simone S, Lampis J, Lasio D, Putzu D. Influences of work-family interface on job and life satisfaction. Appl Res Qual Life. 2014; 9(4):831-61.

84. Ganesh S, Ganesh MP. Effects of masculinity - femininity on quality of work life: understanding the moderating roles of gender and social support. Gend Manag Int J. 2014; 29(4):22953.

85. Wilczyński KM, Swamad MA, Subotic V, Wizner D, Mazgaj E, Wajda W. Factors influencing the levels of work engagement in physicians from Poland, Serbia and Bulgaria. Psychiatr Danub. 2015; 27(Suppl 1):S492-6. 
86. Vayre E, Pignault A. A systemic approach to interpersonal relationships and activities among French teleworkers. New Technol Work Employ. 2014; 29(2):177-92.

87. Olivares A, Bonito J, Silva R. Qualidade de vida no trabalho dos médicos da atenção básica no estado de Roraima (Brasil). Psicol Saúde Doenças. 2015; 16(1):100-11.

88. Oliveira RR, Silva B, Castro DSP, Limongi-França AC. Quality of working life (QWL): a study with teachers from the federal institutes. Hollos. 2015; 6:432-47.

89. Bragard I, Fleet R, Etienne AM, Archambault P, Légaré F, Chauny $J-C$, et al. Quality of work life of rural emergency department nurses and physicians: a pilot study. BMC Res Notes. 2015; 8:116.

90. Mehta P, Kiran R. An empirical analysis of job content and contextual factors: a case study of Indian physicians. Stud Ethno-Med. 2015; 9(3):353-65

91. Mascarenhas CHM, Prado FO, Fernandes MH. Factors associated with the quality of life of community health agents. Ciênc Saúde Colet. 2013; 18(5):1375-86.

92. Yeh HJ. Job demands, job resources, and job satisfaction in East Asia. Soc Indic Res. 2014; 121(1):47-60.

93. Perneger TV, Deom M, Cullati S, Bovier PA. Growing discontent of Swiss doctors, 1998-2007. Eur J Public Health. 2011; 22(4):478-83

94. Bohrer T, Koller M, Schlitt HJ, Bauer H; German Society of Surgery. Workload and quality of life of surgeons. Results and implications of a large-scale survey by the German Society of Surgery. Langenbecks Arch Surg. 2011; 396(5):669-76.

95. Bonab MB, Ebrahimpour D, Ghorbani A. Quality of work life and family functioning in faculty members of Islamic Azad University. Life Sci J. 2012; 10(2s):105-113.

Publish in International Archives of Medicine

International Archives of Medicine is an open access journal publishing articles encompassing all aspects of medical science and clinical practice. IAM is considered a megajournal with independent sections on all areas of medicine. IAM is a really international journal with authors and board members from all around the world. The journal is widely indexed and classified Q2 in category Medicine. 